\title{
The Influence of Teaching Style and Teacher Work Motivation on the Learning Outcomes of Junior High School Students in Beringin Island Sub- District
}

\author{
Eliza Megasari $\left.{ }^{*}\right)$, Yasir Arafat $^{2}$, Alhadi Yan ${ }^{2}$ \\ ${ }^{1}$ SMP Negeri 02 Pulau Beringin OKU, South Sumatra, Indonesia \\ ${ }^{2}$ Universitas PGRI Palembang, Indonesia \\ *Corresponding author.Email: elizamegasari86@gmail.com
}

\begin{abstract}
The study is motivated by a phenomenon that occurs in the teachers at Junior High School in Beringin Island SubDistrict. The purpose of this study was to determine the effect of teaching style and teacher work motivation on student learning outcomes. This study uses quantitative methods with a population of 977 teachers and students for the study sample of 115 respondents. Data collection using questionnaires and documentation of student learning outcomes, then tested using SPSS version 2.5. Hypothesis testing at the 5\% significance level uses the ttest. The result $\mathrm{H} 1$ is accepted, this shows that there is an effect of $17.2 \%$. For H2 to be accepted, this indicates that there is an effect of $18.4 \% \%$. To test the effect simultaneously, the F test is used, the result is $\mathrm{H} 3$ is acceptable, with a large effect of $40.6 \%$. The implication of this research is to be used as input for educators, to implement good teaching styles and build good teacher work motivation in schools.
\end{abstract}

Keywords: Teaching Style, Motivation, Learning Outcomes

\section{INTRODUCTION}

Taking education is an obligatory right for all Indonesian people as the basis for advancing a nation [1]. With the development of the education system every year, there are also methods in the field of education that can be felt by students and teachers. Each year the teaching staff is expected to be able to provide learning to students in accordance with the applicable curriculum. The development of the education system is based on increasingly advanced technological developments. With the development of technology, an important role in achieving student success is fully held by the teaching staff. Along with the development of advances in science and technology, it must be utilized as well as possible in the learning and teaching process.

Each student has different abilities and characters in order to accept the delivery of material given by the teacher [2]. So, the teacher must pay attention to observing the character of their students so that they can adjust to the teaching style being carried out. Based on the research conducted by $\mathrm{Al}$ Khumaero \& Arief (2017) that the teaching style factor based on several indicators such as voice and emphasis have an influence in achieving student learning goals. Teaching style is an approach or technique used by a teacher in conveying the material content of their teaching [3].

Apart from the teacher's teaching style factor, teacher motivation at work also plays a role in the learning process. This is because motivation is the impetus or driving force that causes behavior towards a certain goal [4]. So, it can be concluded that work motivation is an impetus in a person to do or do a task or activity as well as possible in order to achieve high achievement.

Based on the description above, it is concluded that the factors of teaching style and giving motivation to students have an impact on the student achievement process. Therefore, in this research, a study will be conducted on the effect of teaching style methods and teacher motivation on student achievement in Junior High School in Pulau Beringin District. 


\section{THEORETICAL FRAMEWORK}

\subsection{Definition of Teacher}

Teachers are parents of students at school. Teachers have a duty to educate and provide instruction to students. The learning process at school is played by teachers and students. In this case the teacher and students play a role in the learning and teaching process, where the learning process is the core of the overall educational process which aims to change children's behavior [5].

In general, the teacher performance appraisal can be grouped into six main parts, namely: (1) planning lessons; (2) implementing learning; (3) evaluating or assessing the results of learning, (4) guiding extracurricular activities; (5) guiding novice teachers; and (6) self-development. Based on the opinion of Mathis and Jackson (2001) that the factors that affect individual performance at work, namely: (1) ability; (2) motivation; (3) support received; (4) the existence of the work they do; and (5) their relationship with the organization

A professional teacher must have competency standards that can measure the success of teachers in teaching. Law Number 14 of 2005 concerning Teachers and Lecturers, article 10 paragraph 1, explains that teacher competence includes pedagogical competence, personality competence, social competence and professional competence obtained through professional education.

\subsection{Definition of Teaching Style}

The teaching style possessed by a teacher can differ according to the needs in the field. The creativity of a teacher is also a factor in supporting the variety of teaching styles used. The type of variation used in teaching styles can increase students' desire to learn and reduce boredom and boredom in class.

\subsection{Motivation}

According to Hasibuan motivation is the provision of driving forces that create a person's work enthusiasm, so that they are willing to work together, work effectively and are integrated with all their efforts to achieve satisfaction [6]. Teachers who have high work motivation will always work hard to overcome all kinds of problems faced in the hope of achieving better results. Teacher work motivation indicator namely (1) need for achievement; (2) opportunities to be developed; (3) pride in one's own work; (4) the need for recognition; and (5) salary received [7].
The success of the student's teaching and learning process can be influenced by the motivation given. Teachers as educators need to encourage students to learn in achieving goals (1) growing and changing interest in learning; (2) increase enthusiasm for learning; (3) increasing students' attention in learning; and (4) provide optimal conditions for the learning process.

\subsection{The Nature of Learning and Learning}

The main characteristic of learning is the initiation, facilitation and improvement of the student learning process. This shows that the deliberate element of those outside the individual who carry out the learning process, in this case the educator individually or collectively in a system, is the main feature of the learning concept. Keep in mind that not all learning happens on purpose.

\subsection{Learning outcomes}

Learning outcomes can be interpreted as the maximum results achieved by a student after experiencing the teaching and learning process in learning certain subject matter. Learning outcomes are not absolutely in the form of values, but can be in the form of changes, reasoning, discipline, skills and so on that lead to positive changes [8]. Learning outcomes include three domains, namely:

\subsubsection{Cognitive Domain}

Is a realm that includes mental activity (brain). Any effort that includes brain activity is included in the cognitive domain. According to Bloom, there are six levels of the cognitive process, namely: knowledge (memory), understanding, application, analysis, synthetic, and evaluation (assessment).

\subsubsection{Affective Domain}

The taxonomy for the affective area was originally issued by David R. Krathwohl and colleagues in a book entitled "taxonomy of educational objective: affective domain". The affective domain is a domain in which a person's attitude can predictably change if a person has high-level cognitive mastery. The type of affective learning outcomes will appear in students in a variety of behaviors.

\subsubsection{Psychomotor Domain}

The psychomotor learning outcomes were stated by Simpson. These learning outcomes appear in the form of skills (skills) and the ability to act individually. There are six skill levels, namely: reflex movements 
(skills in unconscious movements), skills in conscious movements, perceptual abilities, including distinguishing visuals, distinguishing auditive, motoric and others, abilities in the physical field, such as strength, harmony and consistency, skill movements, from simple skills to complex skills, abilities relating to nondiscursive communication, such as expressive and interpretive movements.

Related to the influence of motivation on employee performance carried out at telecommunications companies in Jakarta that the motivation given has a strong impact on employee performance. Motivation given to employees is self-actualization, self-esteem, social ownership, security and physiological needs. This is shown by looking at the results of the calculation of the correlation coefficient using the SPSS calculation program showing the results of 0.961 with a very strong value category [9].

\section{METHODS}

This research method, quantitative can also be interpreted as a research method based on the philosophy of positivism, used to research on certain populations or samples, data collection using research instruments, quantitative / statistical data analysis, with the aim of testing predetermined hypotheses.

\subsection{Population}

The research population show in the Table 1 .

Table 1. Research population

\begin{tabular}{|c|c|c|c|}
\hline No & School name & $\begin{array}{c}\text { Population } \\
\text { Teacher }\end{array}$ & $\begin{array}{c}\text { Population } \\
\text { Students }\end{array}$ \\
\hline 1. & $\begin{array}{l}\text { Beringin Island Junior } \\
\text { High School } 1\end{array}$ & 45 & 315 \\
\hline 2. & $\begin{array}{l}\text { Beringin Island } 2 \\
\text { Junior High School } \\
\end{array}$ & 37 & 281 \\
\hline 3. & $\begin{array}{l}\text { Beringin Island } 3 \\
\text { Junior High School }\end{array}$ & 34 & 156 \\
\hline 4. & $\begin{array}{l}\text { GB One Roof Junior } \\
\text { High School }\end{array}$ & 18 & 81 \\
\hline & Total & 134 & 833 \\
\hline
\end{tabular}

\subsection{Sample}

The research sample show in the Table 2.

Table 2. Research sample

\begin{tabular}{|c|c|c|c|}
\hline No & School name & $\begin{array}{l}\text { Sample } \\
\text { Teacher }\end{array}$ & $\begin{array}{l}\text { Sample } \\
\text { Students }\end{array}$ \\
\hline 1. & $\begin{array}{l}\text { Beringin Island Junior } \\
\text { High School } 1\end{array}$ & 10 & 25 \\
\hline 2. & $\begin{array}{l}\text { Beringin Island } 2 \text { Junior } \\
\text { High School }\end{array}$ & 10 & 20 \\
\hline 3. & $\begin{array}{l}\text { Beringin Island } 3 \text { Junior } \\
\text { High School }\end{array}$ & 10 & 15 \\
\hline 4. & $\begin{array}{l}\text { GB One Roof Junior } \\
\text { High School }\end{array}$ & 10 & 15 \\
\hline & total & 40 & 75 \\
\hline
\end{tabular}

\subsubsection{Description of teacher work motivation data}

The variable of teacher work motivation in research at SMP $\mathrm{N}$ in Pulau Beringin district was measured using a questionnaire with a Likert scale consisting of 
36 question items. In this research instrument, the validity and reliability were tested first. The teaching style variable score scores ranged from 36 to 180 (Table 4, Figure 2.

Table 4. Description of teacher work motivation data

\begin{tabular}{|l|c|c|c|c|}
\hline No. & $\begin{array}{c}\text { Interval } \\
\text { class }\end{array}$ & Frequency & Percentage & Category \\
\hline 1. & $\begin{array}{c}167- \\
176\end{array}$ & 5 & $12.5 \%$ & Strongly agree \\
\hline 2. & $\begin{array}{c}154- \\
166\end{array}$ & 12 & $30 \%$ & agree \\
\hline 3. & $\begin{array}{c}141- \\
153\end{array}$ & 13 & $32.5 \%$ & Enough \\
\hline 4. & $\begin{array}{c}128- \\
140\end{array}$ & 6 & $15 \%$ & Don't agree \\
\hline 5. & $\begin{array}{c}115- \\
127\end{array}$ & 6 & $15 \%$ & Very disagree \\
\hline
\end{tabular}

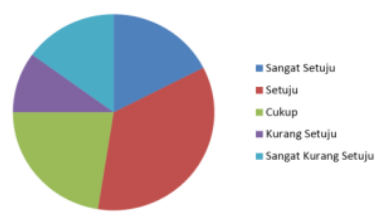

Figure 2. Description of teacher work motivation data

\subsubsection{Description of learning outcome data}

The learning outcome variables in the research at SMPN in the Sub-District of Pulau Beringin were measured using the documentation of the value of the report card leger consisting of 4 existing SMPN schools in the area of Beringin Island. The total sample of students in this study were 75 people (Table 5, Figure 3).

Table 5. Description of learning outcome data

\begin{tabular}{|c|c|c|c|c|}
\hline No. & $\begin{array}{c}\text { Interval } \\
\text { class }\end{array}$ & Frequency & Percentage & Category \\
\hline 1. & $86-89$ & 3 & $4 \%$ & Very good \\
\hline 2. & $81-85$ & 44 & $58.66 \%$ & Good \\
\hline 3. & $76-80$ & 18 & $24 \%$ & Enough \\
\hline 4. & $71-75$ & 5 & $6.67 \%$ & Less \\
\hline 5. & $66-70$ & 5 & $6.67 \%$ & Very less \\
\hline
\end{tabular}

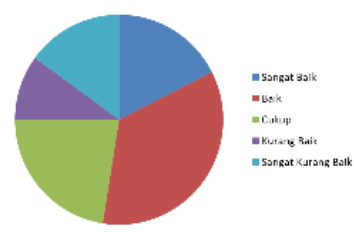

Figure 3. Description of learning outcome data

\subsubsection{Normality test of teaching style variables with student learning outcomes variables}

So it can be explained that the results of the OneSample Kolmogorov-Smimov Test on the normality test above show that the results of Asymp. Sig (2failed) $0.200>0.05$. Therefore, it can be concluded that the data on the teaching style variables and learning outcomes are normally distributed.

\subsubsection{Normality test of teacher work motivation variables with student learning outcomes variables}

So it can be explained that the results of the OneSample Kolmogorov-Smirnov Test on the normality test above show that the results of Asymp. Sig (2failed) $0.200>0.05$. Therefore, it can be concluded that the data on teacher work motivation variables and learning outcomes are stated to be normally distributed.

\subsubsection{Linearity test of teaching style variables with student learning outcomes variables}

So it can be explained that the results of Deviation from Linearity are $0.299>0.05$, therefore it can be concluded that the teaching style variable has a linear relationship with the learning outcome variable. With these results it can also be concluded that the application of teaching styles can provide better learning outcomes.

\subsubsection{Linearity test of teacher work motivation variables with student learning outcomes variables}

So it can be explained that the Deviation from Linearity results are $0.067>\mathrm{r} 0.05$, therefore it can be concluded that the teacher work motivation variable has a linear relationship with the learning outcome variable. teaching styles can provide better learning outcomes.

\subsubsection{Hypothesis testing 1 (H1)}

Hypothesis 1 will be accepted if there is an effect of social media on the learning outcomes of Junior High School students in Pulau Beringin Sub-District, provided that the significance value is $<0.05$, and tcount $>$ t table (Table 6).

Table 6. Hypothesis 1

\begin{tabular}{|c|c|c|c|c|c|}
\hline \multicolumn{6}{|c|}{ Coefficients $^{\mathrm{a}}$} \\
\hline \multirow[b]{2}{*}{ Model } & \multicolumn{2}{|c|}{ Unstandardized Coefficients } & \multirow{2}{*}{$\begin{array}{c}\text { Standardized Coefficients } \\
\text { Beta }\end{array}$} & \multirow[b]{2}{*}{$t$} & \multirow[b]{2}{*}{ Sig. } \\
\hline & B & Std. Error & & & \\
\hline 1 (Constant) & 63.091 & 5.737 & & 10.997 & .000 \\
\hline GayaMengajar_X & .168 & .060 & .415 & 2.810 & .008 \\
\hline
\end{tabular}

a. Dependent Variable: HasilBelajar_Y

It is known that the significance value for the teaching style variable $(\mathrm{X})$ is $0.008<0.05$ and tcount $2.810>$ ttable 2.02439 , thus it can be concluded that $\mathrm{H} 01$ is accepted, 


\subsubsection{Hypothesis testing 2 (H2)}

Hypothesis 2 will be accepted if there is an influence of social media on the learning outcomes of Junior High School students in Pulau Beringin SubDistrict, provided that the significance value is $<0.05$, and tcount $>t$ table (Table 7).

Table 7. Hypothesis 2

\begin{tabular}{|c|c|c|c|c|c|}
\hline \multicolumn{6}{|c|}{ Coefficients ${ }^{a}$} \\
\hline \multirow[b]{2}{*}{ Model } & \multicolumn{2}{|c|}{ Unstandardized Coefficients } & \multirow{2}{*}{$\begin{array}{c}\text { Standardized Coefficients } \\
\text { Beta }\end{array}$} & \multirow[b]{2}{*}{$t$} & \multirow[b]{2}{*}{ Sig. } \\
\hline & B & Std. Error & & & \\
\hline 1 (Constant) & 59.061 & 6.889 & & 8.573 & .000 \\
\hline MotivasiKerja_X1 & .134 & .046 & .428 & 2.923 & .006 \\
\hline pendent Variab & HasilBelaj & & & & \\
\hline
\end{tabular}

It is known that the significance value for the teacher work motivation variable $(\mathrm{X} 1)$ is $0.006<0.05$ and tcount $2.923>$ ttable 2.02439 , thus it can be concluded that $\mathrm{H} 02$ is accepted.

\subsubsection{Hypothesis testing 3 (H3)}

Hypothesis 3 will be accepted if there is an influence of social media on the learning outcomes of Junior High School students in Pulau Beringin SubDistrict, provided that the significance value is $<0.05$, and Fcount $>t$ table (Table 8).

\section{Table 8. Hypothesis 3}

\begin{tabular}{|c|c|c|c|c|c|c|}
\hline \multicolumn{7}{|c|}{ ANOVA $^{2}$} \\
\hline \multicolumn{2}{|c|}{ Model } & Sum of Squares & $d f$ & Mean Square & $\mathrm{F}$ & Sig. \\
\hline \multirow[t]{3}{*}{1} & Regression & 142.183 & 2 & 71.092 & 4.171 & $.023^{t}$ \\
\hline & Residual & 630.626 & 37 & 17.044 & & \\
\hline & Total & 772.809 & 39 & & & \\
\hline \multicolumn{7}{|c|}{ a. Dependent Variable: SKOR_HB } \\
\hline \multicolumn{7}{|c|}{ b. Predictors: (Constant), SKOR_MK, SKOR_GM } \\
\hline
\end{tabular}

It is known that the significance value is 0.23 in the sense that the value is $0.023<0.05$ and Fcount $4.171>$ Ftable 3.25 , so the conclusion is that there is an effect of variable $\mathrm{X}$ and variable $\mathrm{X} 1$ together on variable $\mathrm{Y}$ or $\mathrm{H} 03$ is accepted.

\subsection{Discussion}

\subsubsection{The influence of teaching style variables on learning outcomes}

The results of this study are consistent with the research conducted by Al Khumaero \& Arief (2017) in his research entitled the effect of teacher teaching style, learning discipline and peers on learning achievement. The results of his research showed that the significance reached a value of $0.002<0.05$, which means that there is an effect of teaching style on student achievement. This also shows that the better the teaching style of the teacher, the better the learning achievement obtained by students.

\subsubsection{The influence of work motivation variables on learning outcomes}

This research is in line with this research conducted by other researchers. In his research entitled the effect of teacher work motivation on the performance of vocational school accounting teachers in Madiun, it shows the results for Rsquares of $80.6 \%$, this indicates that the variables used have an influence on the learning outcomes process while the remaining percentage is influenced by other variables not used in the study [10].

\subsubsection{The influence of teaching style variables and work motivation on learning outcomes}

This research is in line with the research conducted by [11] regarding the effect of teacher teaching style on science learning achievement at MI Ma'arif NU Sanguwatang, Karangjambu District, Purbalingga Regency that there is an influence of teaching style with a coefficient of determination or Rsquare of 0.760 in the sense that this is influenced by $76 \%$ by teaching style.

\section{CONCLuSION}

From this research, the conclusions are: (1) The influence of teaching style on student learning outcomes at Pulau Beringin Junior High School, (2) There is an effect of teacher work motivation on student learning outcomes at Pulau Beringin Junior High School, and (3) The simultaneous influence of style teaching and teacher work motivation on student learning outcomes at Junior High School students in Pulau Beringin Sub-District. For teachers to enrich their knowledge about how to teach attractive styles and have high motivation in the learning and teaching process.

\section{REFERENCES}

[1] Sujatmoko, E. (2016). The right of citizens to obtain education. Journal of the Constitution, 7 (1).

[2] Triumiana, DA, \& Sumadi, S. (2017). The relationship between teacher teaching style, student learning motivation and student learning creativity with physics learning achievement. Compton: Scientific Journal of Physical Education, 3 (2).

[3] Septiana Andri Astutie, C. (2013). The Effect of Teacher Teaching Styles and Student Learning Styles on Learning Outcomes of Economics 
Subjects in Class X SMA Negeri 18 Surabaya. Journal of Economic Education (JUPE), 1 (3).

[4] Lomu, L., \& Widodo, SA (2018). The Effect of Learning Motivation and Discipline on Students' Mathematics Learning Achievement. Paper presented at the Proceedings of a national seminar on ethnomatnesian mathematics education.

[5] Kirom, A. (2017). The role of teachers and students in the multicultural-based learning process. Al Murabbi, 3 (1), 69-80.

[6] Assagaf, SCY, \& Dotulong, LO (2015). The Influence of Discipline, Motivation and Work Spirit on Work Productivity of Regional Revenue Service Employees in Manado City. EMBA Journal: Journal of Economic Research, Management, Business and Accounting, 3 (2).

[7] Wahyudi, A., Thomas, P., \& Setiyani, R. (2012). The Influence of Work Discipline, Work Motivation, and Principal Supervision on Teacher Performance. Economic Education Analysis Journal, 1 (2), 1-8.

[8] Turrohmah, M. (2017). The relationship between the professional competence of the Hadith Qur'an teachers and learning motivation on student learning outcomes in Ma Nurul Ulum Tulungagung, Gading Rejo District, Pringsewu Regency. UIN Raden Intan Lampung.

[9] Kurniasari, R. (2018). Giving Motivation and Its Impact on Employee Performance at Telecommunication Companies in Jakarta. Widya Cipta: Journal of Secretarial and Management, 2 (1), 32-39.

[10] Ardiana, TE (2017). The influence of teacher work motivation on the performance of accounting teachers in SMK in Madiun City. Journal of Accounting and Tax, 17 (02).

[11] Setianingrum, D. (2017). The Effect of Teacher Teaching Style on Science Learning Achievement at MI Ma'arif NU Sanguwatang, Karangjambu District, Purbalingga Regency. IAIN.

[12] Pambudi, B. A., \& Gunawan, I. (2019, December). Instructional Leadership as an Effort to Increase Teacher Professionalism in the Industrial Revolution Era 4.0. In the 4th International Conference on Education and Management (COEMA 2019). Atlantis Press.

[13] Gunawan, I. I. (2017, August). The Application of Instructional Management Based Lesson Study and Its Impact with Student Learning Achievement. In 2nd International Conference on Educational Management and Administration (Coema 2017). Atlantis Press.

[14] Sobri, A. Y., Bafadal, I., Nurabadi, A., \& Gunawan, I. (2018, October). Development of Mentoring Modules Based on Self-Reflection for Beginner Principal. In 3rd International Conference on Educational Management and Administration (Coema 2018). Atlantis Press.

[15] Kusumaningrum, D. E., Sumarsono, R. B., \& Gunawan, I. (2019). Professional Ethics and Teacher Teaching Performance: Measurement of Teacher Empowerment with A Soft System Methodology Approach. International Journal of Innovation, Creativity and Change, 5(4), 611624. 